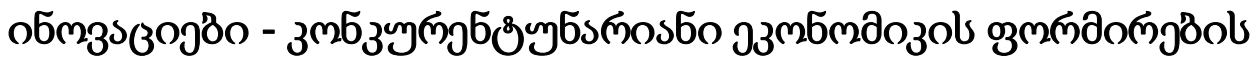 дбодзбјмммзьбо зокмдs
}

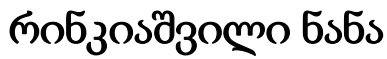

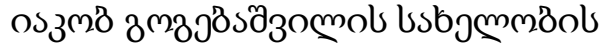

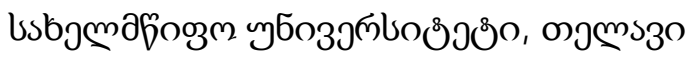

https://doi.org/10.52340/idw.2021.530

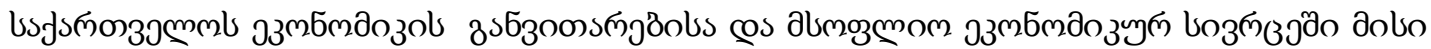

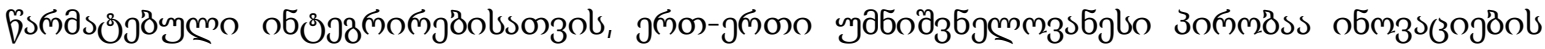

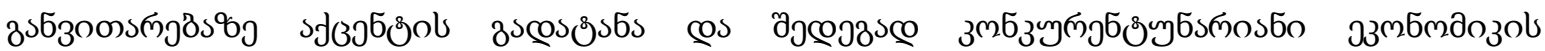

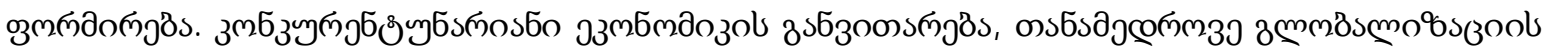

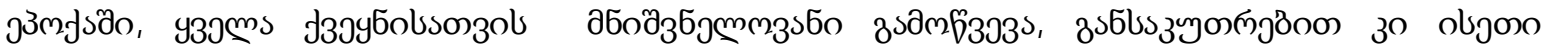

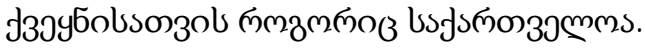

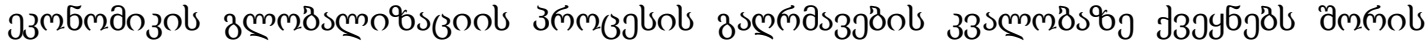

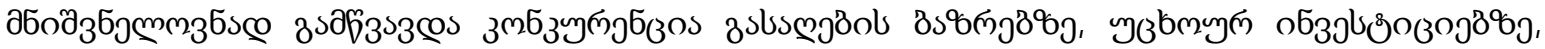

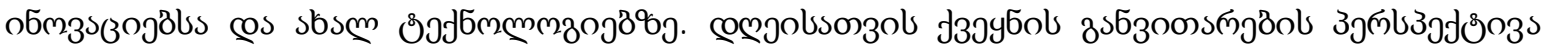

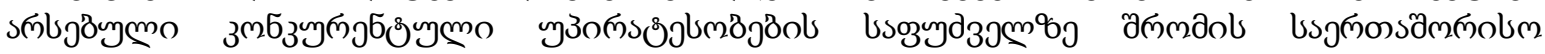

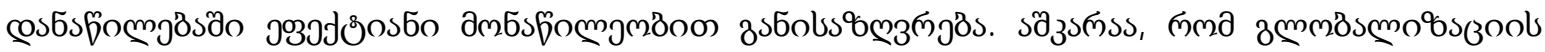

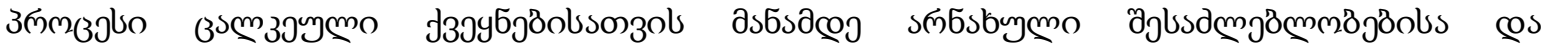

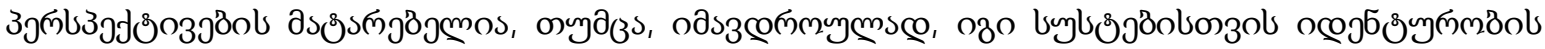

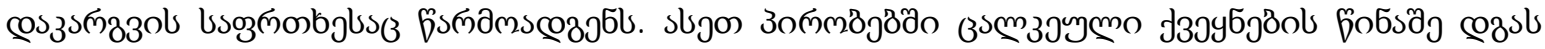

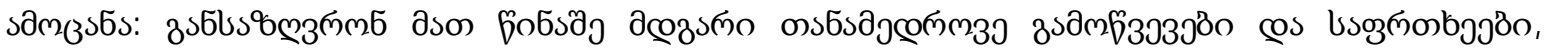

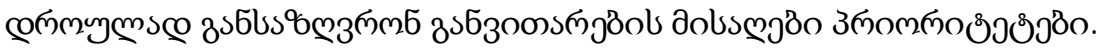

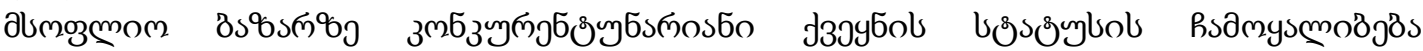

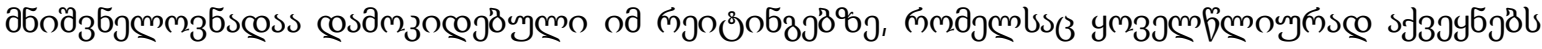

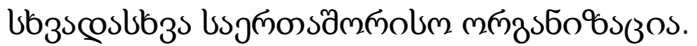

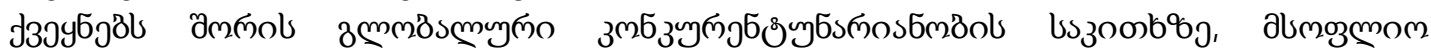

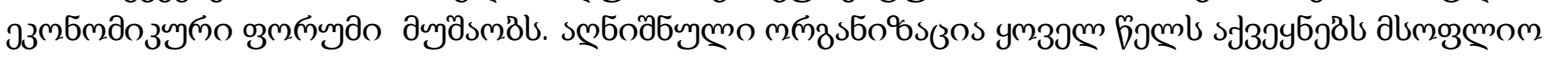

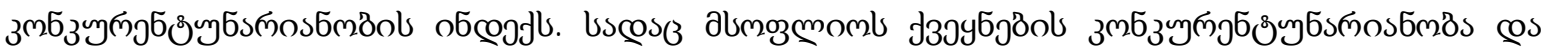

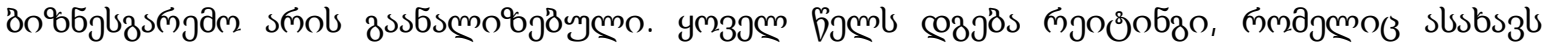

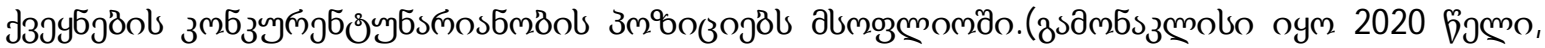

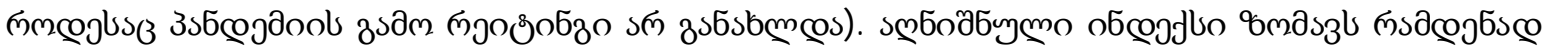

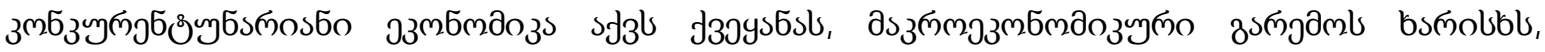

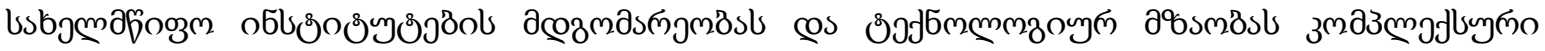

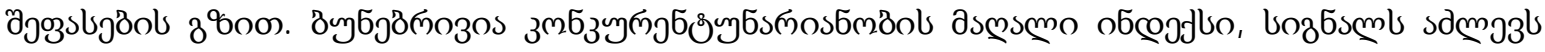

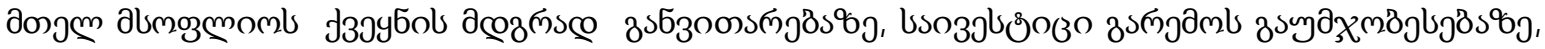

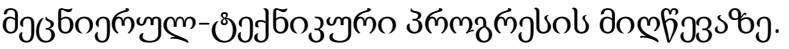

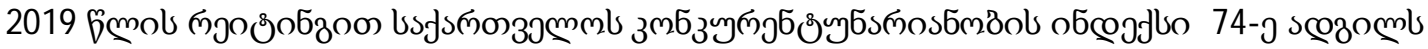

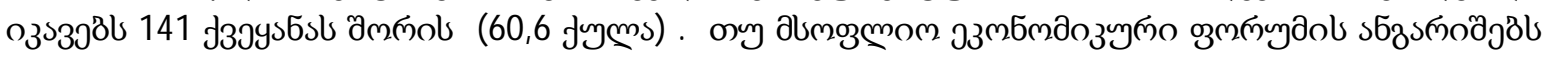

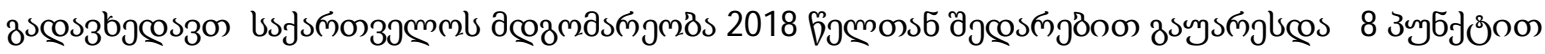

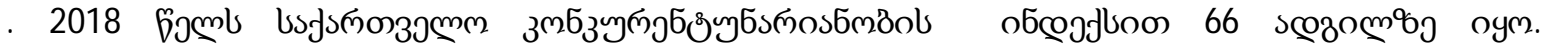

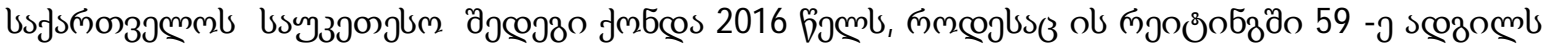
озร3ว

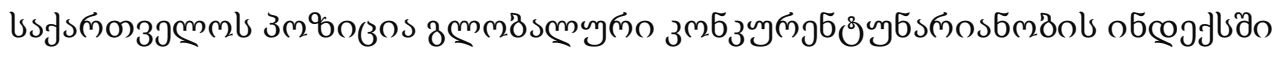




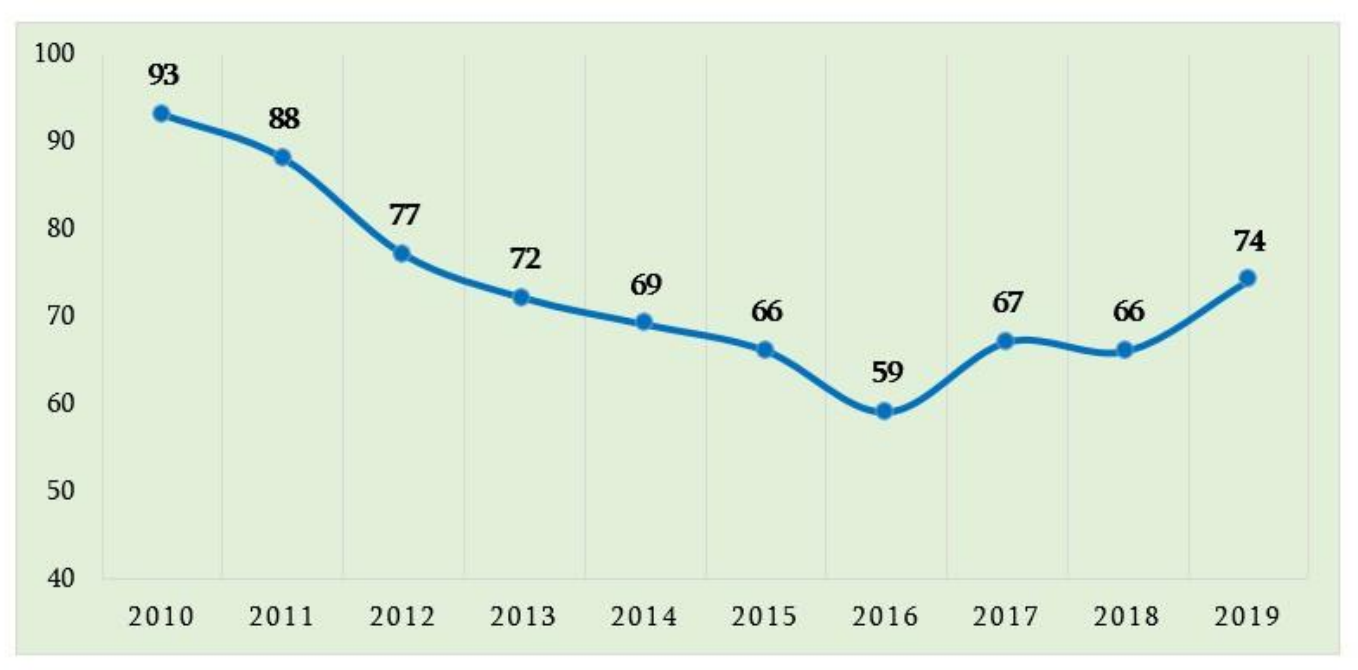

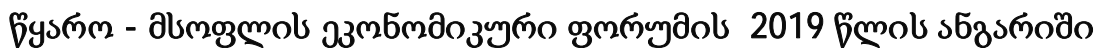

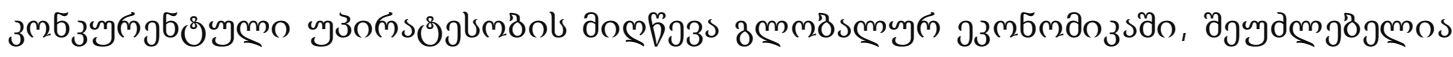

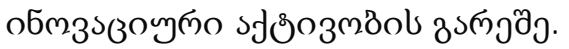

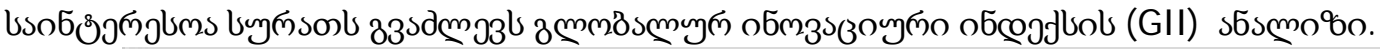

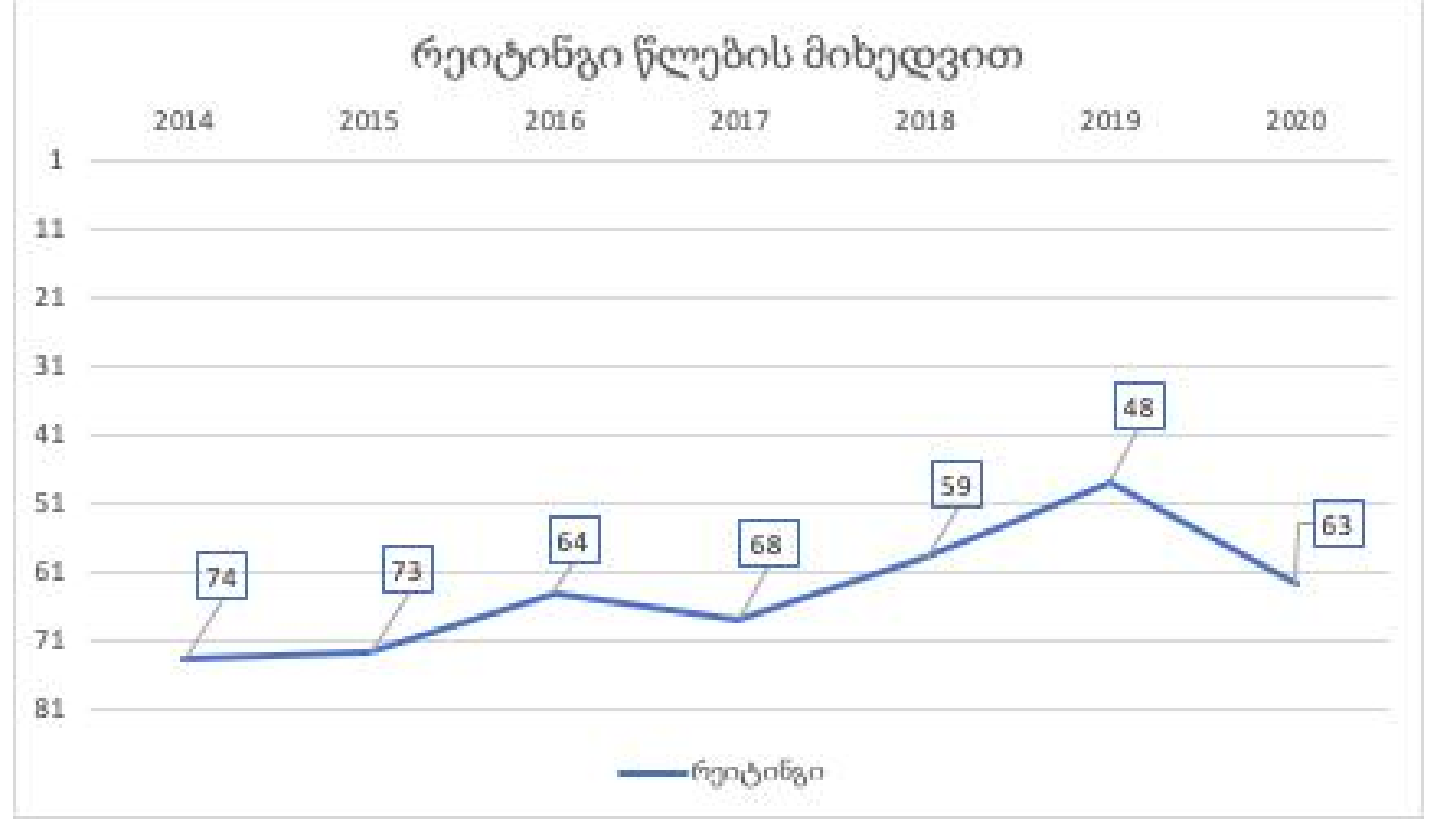

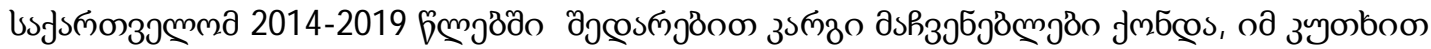

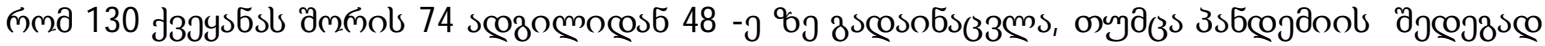

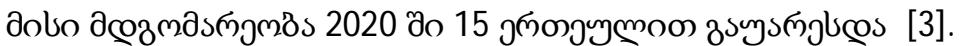

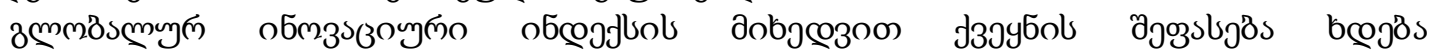

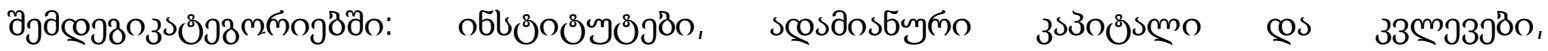

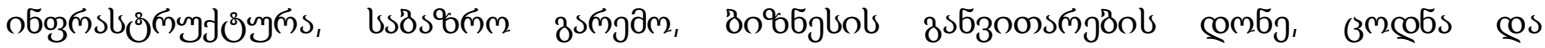

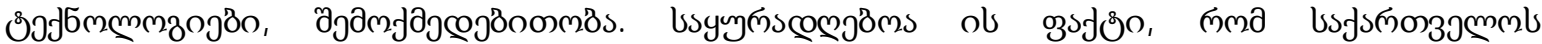

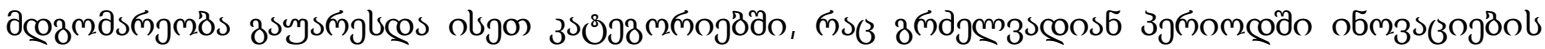

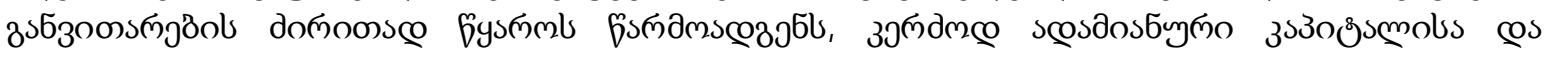




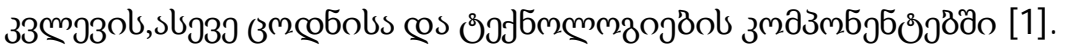

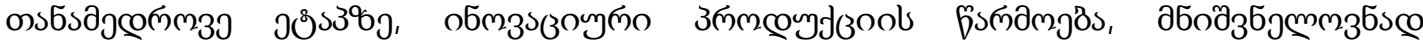

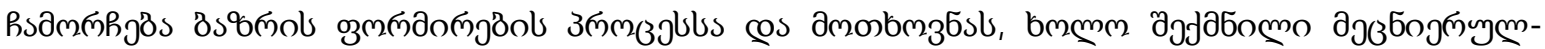

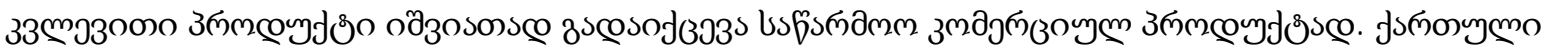

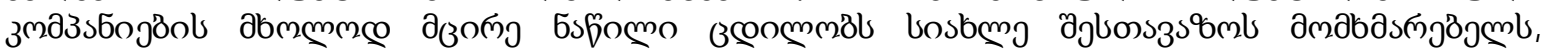

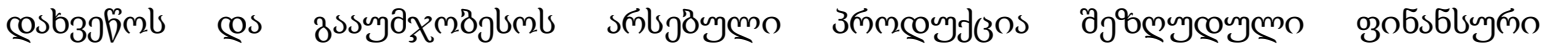
дjlsdm

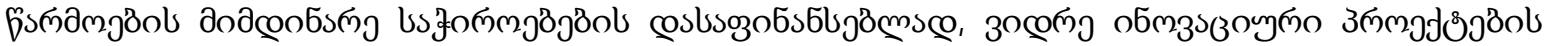

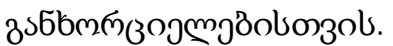

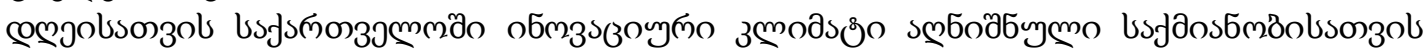

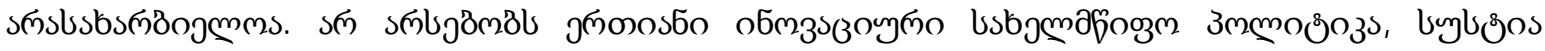

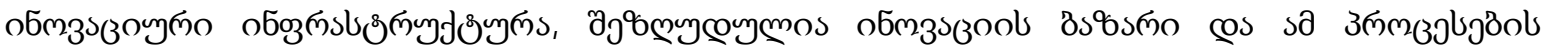

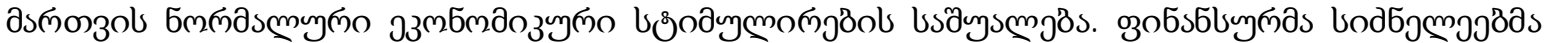

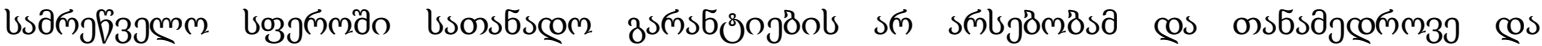

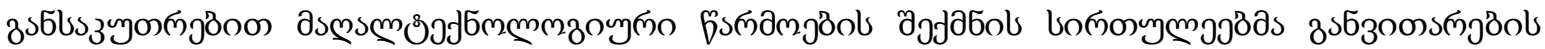

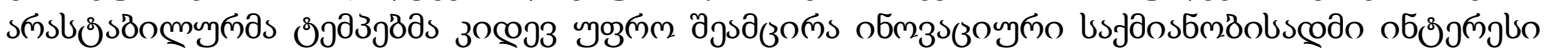

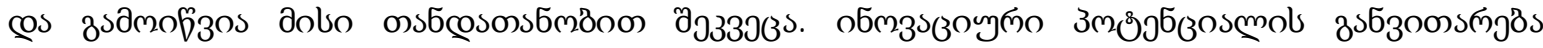

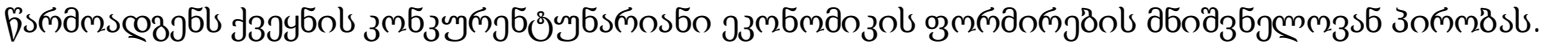

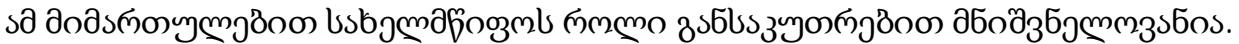

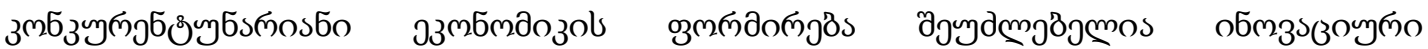

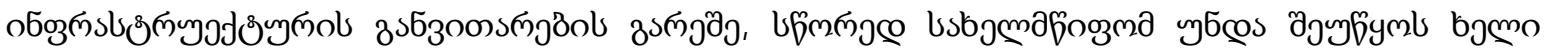

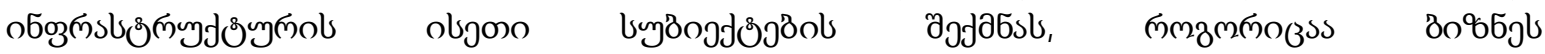

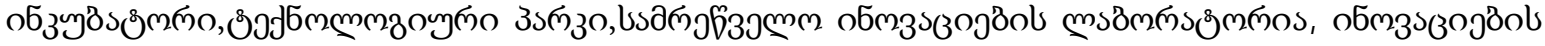

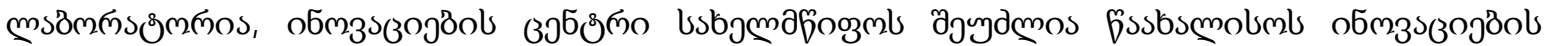

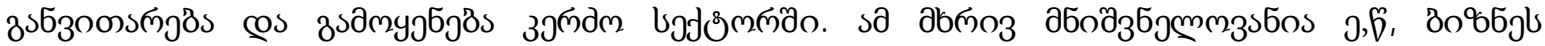

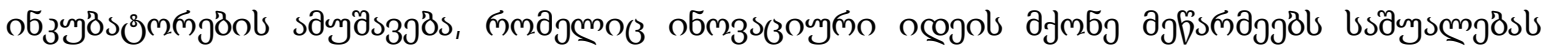
sdm

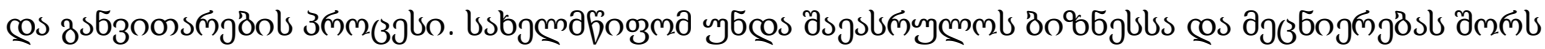

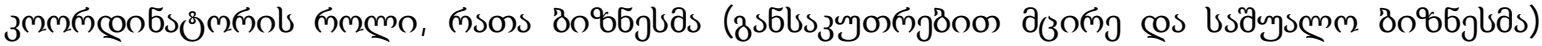

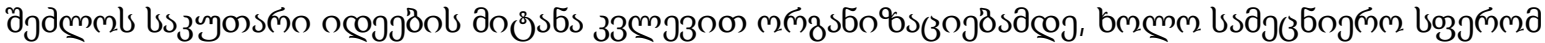

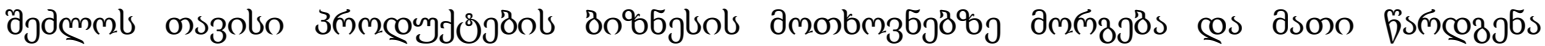

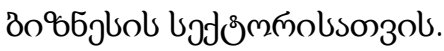

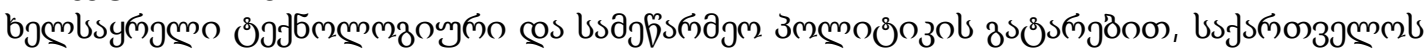

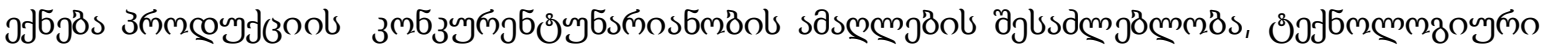

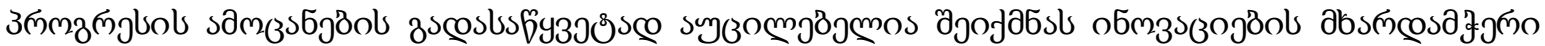

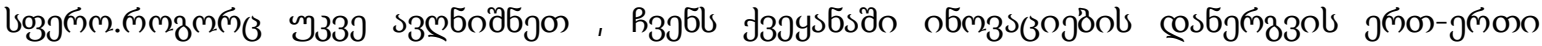

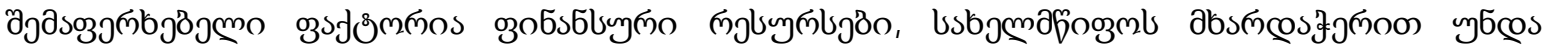

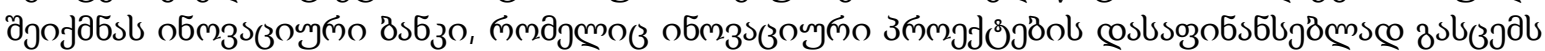

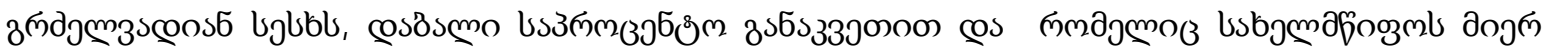

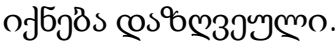

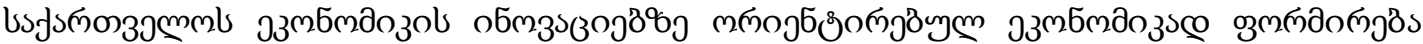

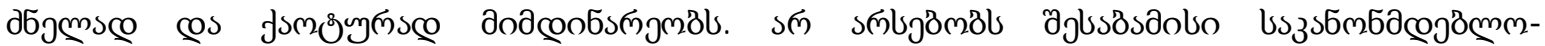

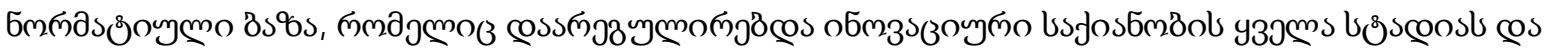

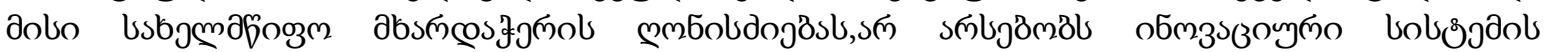

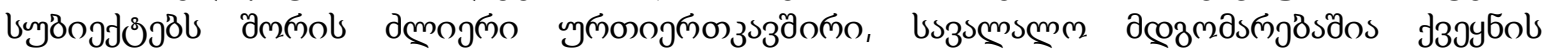

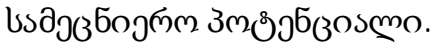

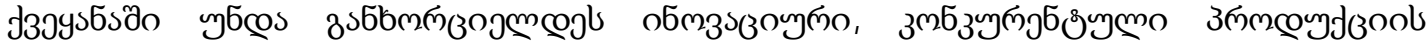

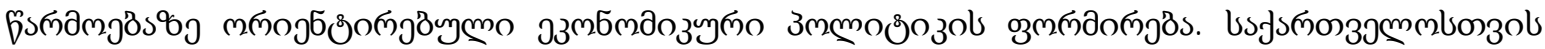

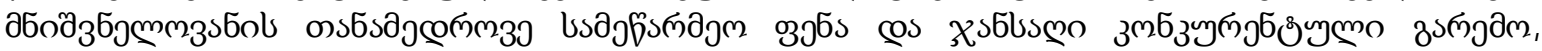

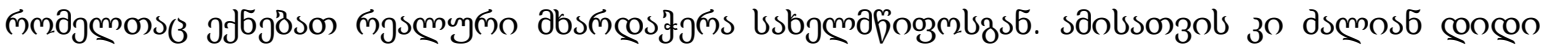




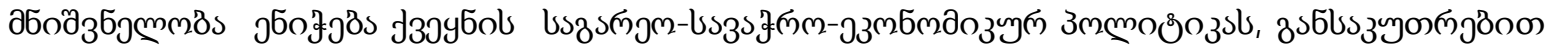

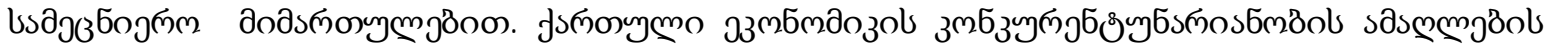

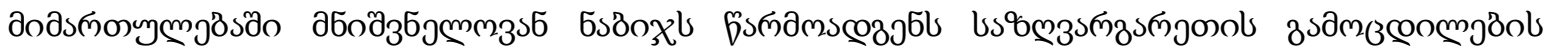

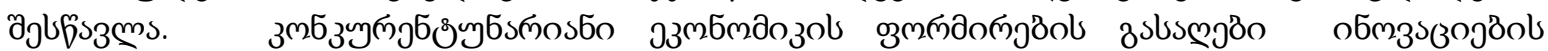

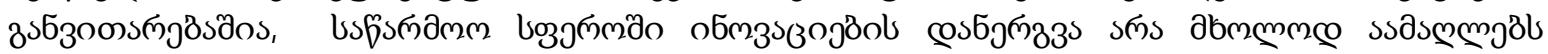

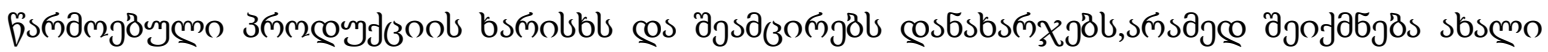

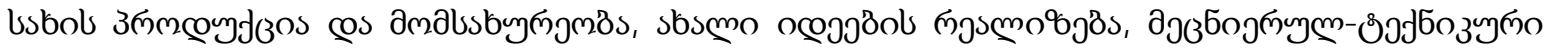

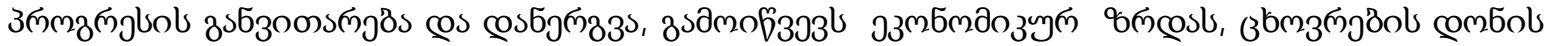

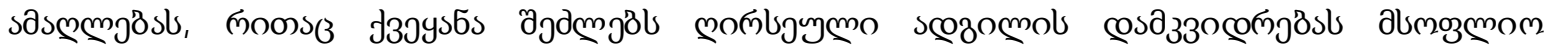

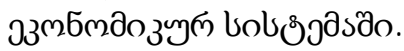

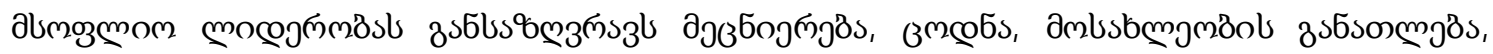

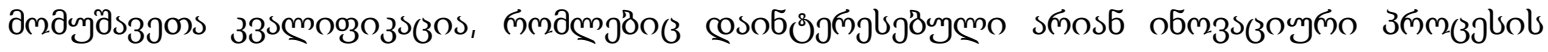

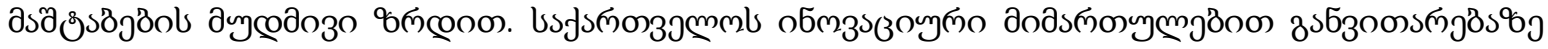

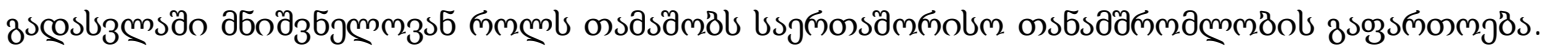

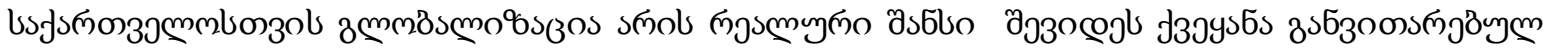

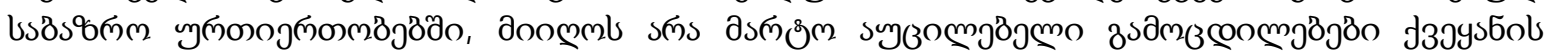

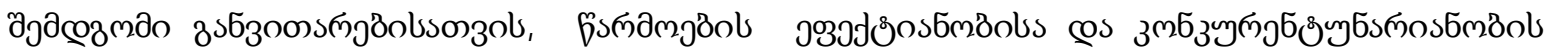

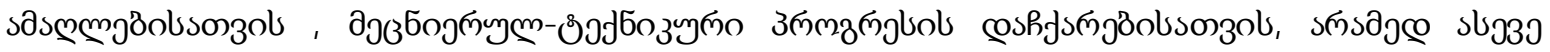

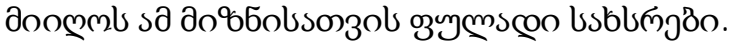

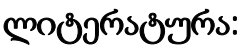

1. https://forbes.ge/blogs/saqarthvelo-globaluri-konkurentunarianobis-reitingshi/

2. https://matsne.gov.ge/ka/document/view/3322328?publication=0

3. https://idfi.ge/ge/georgia_in_the_global_innovation_inde

4. http://press.tsu.ge/data/image_db_innova/Gaganidze.pdf

\section{Innovation - an Important Condition for the Formation of a Competitive Economy}

\section{Rinkiashvili Nana}

Iakob Gogebashvili State University, Telavi

\section{Abstract}

One of the most important conditions for the development of the Georgian economy and its successful integration into the world economic space is to focus on the development of innovations and, as a result, to form a competitive economy.

At present, the innovative climate in Georgia is not favorable for the formation of a competitive economy. There is no unified innovative state policy, weak innovation infrastructure, limited innovation market and normal economic stimulus to manage these processes. Financial difficulties, lack of proper guarantees in the industrial field and difficulties in creating modern and especially in high-tech production area, unstable pace of development further reduced the interest in innovative activities and led to its gradual decline. As a result, Georgia ranks 74th place among 141 countries in the Competitiveness Index. In the modern global space, the development of innovative potential is an important condition for the formation of a competitive economy of the country.

In the article we focused on some of the problems of innovative development and its solution. The competitiveness potential of the country is analyzed, the role of the state in the formation of a competitive economy through the development of innovations is given.

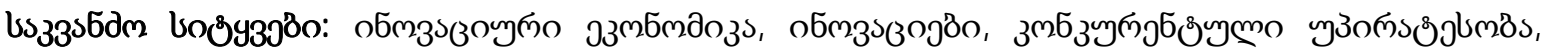

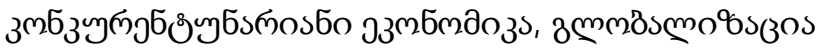

Keywords: Innovative Economy; Innovation; Competitive Advantage; Competitive Economy; Globalization. 